\title{
Storability research with starch potato cultivars
}

R. Wustman ${ }^{1}$, P. S. Hak ${ }^{1}$ and P. Plieger ${ }^{2}$ ( ${ }^{1}$ Institute for Research on Storage and Processing of Agricultural Produce (IBVL), P.O. Box 18, 6700 AA Wageningen, Netherlands; ${ }^{2}$ NIKO-TNO, Rouaanstraat 27, 9723 CC Groningen, Netherlands)

Received 16 September 1986; accepted 31 October 1986

\begin{abstract}
Four years of storability research with starch potato cultivars grown on peat soils in the Netherlands resulted in distinct cultivar differences with respect to losses in tuber weight, starch and weight on payment, and to rot development. Cultivar Astarte was found to have high losses, and cvs. Elkana and Prominent low losses. Astarte showed a high susceptibility to internal and external damage. Elkana, Atrela and Prominent were very susceptible to sugar accumulation from starch conversion at lower temperatures.
\end{abstract}

Key words: storability, starch potato, weight loss, rot development

Introduction. The starch processing industry in the northeastern part of the Netherlands needs to store a substantial part of its raw material since its processing capacity was reduced in the late $1970 \mathrm{~s}$. Clamps and modified farm buildings were developed for short-term and medium-term storage with low capital investment (Hak, 1983). In the process of developing such systems, it was found that starch potato cultivars differed in storage behaviour, implying that cultivars from a similar origin varied largely in level of losses.

In 1982 storability research was started at IBVL and NIKO-TNO (previously PAV-TNO) and concentrated on commercially grown cultivars and promising but not yet released cultivars.

Materials and methods. During the period 1982-1986 all tested cultivars were grown on peat soils in the northeastern part of the Netherlands. The commercially grown cultivars included in the trials were: Astarte (1982/86), Elkana (1982/86), Producent (1982/86), Atrela (1982/85), Promesse (1982/85), Prominent (1983/86), Mentor (1983/85), Darwina (1983/84), Element (1983/84) and Prevalent (1985/86). The promising, but not yet released cultivar Elles was studied in 1984/85 only.

During 1982/85 most crops were harvested either mature or almost mature. To be sure about a similar handling, all potatoes were harvested by hand. All samples contained 50 tubers of $40-60 \mathrm{~mm}$. The number of samples per object was 19 in $1982 /$ 83,24 in 1983/84, 20 (late maturing cultivars) and 32 (very late maturing cultivars) in $1984 / 85$ and 16 in $1985 / 86$.

To test the storability of starch potatoes the following characteristics were analysed:

- susceptibility to internal and external damage 
- susceptibility to rot diseases

- sprouting behaviour

- loss of weight

- loss of weight on payment

- susceptibility to sugar accumulation from starch conversion

- susceptibility to Fusarium spp.

To simulate mechanical harvesting in practice, all samples were treated for 15 seconds in a shaking apparatus (Meijers, 1981). Two samples per cultivar were shaken for 45 seconds. After a wound healing period of about 2 weeks at $15^{\circ} \mathrm{C}$ and $95 \% \mathrm{RH}$, most material was stored at $6{ }^{\circ} \mathrm{C}$, being the recommended storage temperature for starch potatoes.

A limited amount of the material was stored at $20{ }^{\circ} \mathrm{C}$ and ca. $95 \%$ RH for measuring susceptibility to rot diseases, which was indicated as rot index. This rot index was calculated as follows: $r o t$ index $=1 \times$ low rot incidence (in $\%)+2 \times$ medium rot incidence (in \%) $+4 \times$ heavy rot incidence (in \%). According to this formula the maximum rot index is 400 .

Results. Table 1 shows the results of the rot indices and losses of gross and net weight, starch, dry matter and weight on payment and the accumulation of sugars when potatoes are stored at lower temperatures.

Loss of weight on payment, the most relevant one for the grower, was largest for Astarte, Atrela and Producent, and lowest for Elkana, Mentor and Element.

Table 1. Results of storability research with starch potato cultivars when stored at $6{ }^{\circ} \mathrm{C}$ and at $20{ }^{\circ} \mathrm{C}$ and $95 \% \mathrm{RH}$. In parenthesis: number of research seasons per cultivar; 1982-1985.

\begin{tabular}{|c|c|c|c|c|c|c|c|c|c|c|c|}
\hline Cultivar & \multicolumn{3}{|c|}{$\begin{array}{l}\text { Average } \\
\text { rotindex } \\
\text { at } 20^{\circ} \mathrm{C}\end{array}$} & \multicolumn{2}{|c|}{$\begin{array}{l}\text { Average } \\
\text { gross } \\
\text { weight } \\
\text { loss }(\%) \\
\text { at } 20^{\circ} \mathrm{C}\end{array}$} & $\begin{array}{l}\text { Average } \\
\text { gross } \\
\text { weight } \\
\text { loss }(\%) \\
\text { at } 6^{\circ} \mathrm{C}\end{array}$ & $\begin{array}{l}\text { Average } \\
\text { net } \\
\text { weight } \\
\text { loss }(\%) \\
\text { at } 6^{\circ} \mathrm{C}\end{array}$ & $\begin{array}{l}\text { Average } \\
\text { loss of } \\
\text { dry mat- } \\
\text { ter }(\%) \\
\text { at } 6^{\circ} \mathrm{C}\end{array}$ & $\begin{array}{l}\text { Average } \\
\text { loss of } \\
\text { starch } \\
(\%) \\
\text { at } 6^{\circ} \mathrm{C}\end{array}$ & $\begin{array}{l}\text { Average } \\
\text { loss of } \\
\text { weight on } \\
\text { payment }(\%) \\
\text { at } 6^{\circ} \mathrm{C}\end{array}$ & $\begin{array}{l}\text { Average } \\
\text { increase in } \\
\text { content of } \\
\text { total sugars } \\
(\%) \text { at } 6{ }^{\circ} \mathrm{C}\end{array}$ \\
\hline $\begin{array}{l}\text { Shaking } \\
\text { period (s) }\end{array}$ & $\rightarrow$ & 15 & 45 & 15 & 45 & 15 & 15 & 15 & 15 & 15 & 15 \\
\hline Astarte & (3) & 23.5 & 134 & 11.6 & 19.8 & 8.8 & 8.7 & 3.7 & 6.2 & 7.6 & 64 \\
\hline Atrela & (3) & 23 & 13 & 10.9 & 4.9 & 8.3 & 8.4 & 6.0 & 9.5 & 7.5 & 121 \\
\hline Darwina & (2) & 29 & 181.5 & 13.6 & 26 & 8.0 & 7.5 & 3.4 & 5.2 & 3.8 & 98 \\
\hline Element & (1) & 19 & 48 & 5.5 & 6.5 & 8.3 & 8.3 & 2.2 & 5.2 & 2.8 & 79 \\
\hline Elkana & (3) & 2 & 17 & 7.5 & 8.5 & 5.9 & 5.8 & 3.8 & 7.6 & 2.4 & 122 \\
\hline Elles & (1) & 9 & 59 & 13.0 & 16.6 & 7.6 & 7.6 & 4.3 & 6.7 & 6.3 & 104 \\
\hline Mentor & (2) & 16 & 80 & 11.4 & 12.7 & 6.8 & 6.6 & 3.7 & 5.4 & 1.7 & 108 \\
\hline Producent & (3) & 26.5 & 169.5 & 12.9 & 21.1 & 10.3 & 10.1 & 6.1 & 10.1 & 7.0 & 112 \\
\hline Promesse & (3) & 25.5 & 63 & 19.7 & 9.7 & 7.2 & 7.3 & 3.3 & 6.2 & 3.1 & 79 \\
\hline Prominent & (2) & 18 & 46 & 11.5 & 13.8 & 8.6 & 8.5 & 6.1 & 8.5 & 4.6 & 151 \\
\hline Average & & 22.6 & 93.8 & 11.3 & 14.0 & 8.2 & 8.1 & 4.6 & 7.5 & 6.3 & 104 \\
\hline
\end{tabular}


Table 2. Percentage of weight loss (WL) and loss of weight on payment (WLP) per maturity stage of starch potato cultivars $1985-86$.

\begin{tabular}{|c|c|c|c|c|c|c|}
\hline \multirow[t]{3}{*}{ Cultivar } & \multicolumn{6}{|c|}{ Loss 140 days after harvest $(\%)$} \\
\hline & \multicolumn{2}{|c|}{ immature } & \multicolumn{2}{|c|}{ haulm-pulled } & \multicolumn{2}{|c|}{ mature } \\
\hline & WL & WLP & WL & WLP & WL & WLP \\
\hline Astarte & 18.0 & 26.7 & 17.8 & 12.7 & 15.4 & 15.7 \\
\hline Elkana & 6.1 & 1.4 & 8.6 & 9.7 & 7.0 & 5.0 \\
\hline Prevalent & 7.7 & 2.6 & 12.5 & 7.4 & 16.5 & 3.4 \\
\hline Prominent & 6.5 & 1.5 & 13.1 & 6.2 & 10.1 & 12.0 \\
\hline
\end{tabular}

Some cultivars tend to convert starch into sugars when stored at lower temperatures. Although this is not an immediate loss to the grower, it does imply a loss to the processing factory, as sugars dissolve during the production of starch from the tubers. A cultivar susceptible to sugar formation is therefore less suitable for storage at low temperatures. In particular Elkana, Atrela and Prominent show this susceptibility, Astarte and Promesse are much less susceptible (Table 1).

Note added (not treated in the report supporting this synopsis). During 1985/86 it was found that crops harvested 3 weeks after haulm-pulling or mature crops showed higher losses than immature crops (Wustman \& Zinsmeester, 1986). Willcockson et al. (1985) worked with Pentland Crown potatoes and found that delay of the harvest date usually increased weight loss. They also found that lenghening the interval from haulm-pulling until harvest usually increased weight loss in storage.

\section{References}

Hak, P. S., 1983. Principe van kuilbewaring. Bedriffsontwikkeling. 14: 795-798.

Meijers, C. P., 1981. Diseases and defects liable to affect potatoes during storage. In: A. Rastovski; A. van Es et al., Storage of potatoes. Post-harvest behaviour, store design, storage practice, handling, $p$. 138-166. Pudoc, Wageningen, $462 \mathrm{pp}$.

Willcockson, S. J., E. J. Allen, R. K. Scott \& D. C. E. Wurr, 1985: Effect of crop husbandry and growing conditions on storage of Pentland Crown potatoes. Journal of Agricultural Science, Cambridge 105: 413-435.

Wustman, R., P. Plieger \& P. S. Hak, 1986. Bewaaronderzoek met tien fabrieksaardappelrassen in seizoen 1984-1985. IBVL Report 537/NIKO-TNO Report 2709.

Wustman, R. \& C. Zinsmeester, 1986. Bewaarbaarheidsonderzoek met acht fabrieksaardappelrassen; 1985-1986. IBVL Report 601/NIKO-TNO Report 2778.

This synopsis is based on a report entitled 'Samenvatting van drie seizoenen bewaaronderzoek met fabrieksaardappelrassen in 1982-1985', IBVL-Rapport 599/NIKOTNO-Rapport 2776, 1986. 28 pp., 17 tables, 5 refs. Dutch.

Available as paper copy (order R065P, $f 13$ including postage) or microfiches (or$\operatorname{der} R 065 M, f$ 12.50) at: NARD, clo Pudoc, P.O. Box 4, 6700 AA Wageningen, Netherlands (telex $45015 \mathrm{blhwg}$ ). 